\title{
Socio Economic Status of the People Adopting Bee Keeping as an Entrepreneurship
}

\author{
Bhupender Singh $^{1 *}$, Surender Singh ${ }^{2}$ and Asha Batra ${ }^{3}$ \\ ${ }^{1}$ (Ento), ${ }^{2}$ (Hort), ${ }^{3}$ (EECM), Saina Nehwal Institute of Agricultural Technology Training and \\ Education, Directorate of Extension Education, Chaudhary Charan Singh Haryana \\ Agricultural University, Hisar-125004, Haryana, India \\ *Corresponding author
}

\section{A B S T R A C T}

\section{Keywords}

Adoption, Bee keeping,

Entrepreneurship, Perception, Socioeconomic status

\section{Article Info}

Accepted:

04 June 2018

Available Online:

10 July 2018
The present study was carried out at SainaNehwal Institute of Agricultural Technology, Training and Education, Chaudhary Charan Singh Haryana Agricultural University, Hisar (Haryana) during 2016-17. Response of the trainees was evaluated on the basis of gender, age, educational status, occupation and adoption of bee keeping as an entrepreneurship. Majority of respondents $(96 \%)$ were male; belonged to young age group (72\%), having education level up to matriculation (47\%) and farming as an occupation (51\%). Majority of respondents $(67 \%)$ were either landless/tenant or marginal farmers and about 73 per cent were having low level of annual income. More than $3 / 4^{\text {th }}$ of the respondents $(82 \%)$ showed the interest in adopting bee keeping as an entrepreneurship. It was concluded that the unemployed youth, landless labors/farmers and marginal farmers belonging to young age group having low level of annual income are more interested in adopting bee keeping as an entrepreneurship.

\section{Introduction}

Indian economy is agriculture based where more than 60 per cent population of the country depend on agriculture and its allied sector for livelihood. But due to increase in population pressure and industrialization, the per capita land holding is decreasing day by day. Also, a large proportion of the youth, particularly in rural area is unemployed due to poor opportunities of job in government sector and lack of skill for creating self-employment. Thus, it has become very difficult for a landless/marginal/small farmer and unemployed people to meet out the domestic needs of the family. Under such conditions, these people have to adopt some other high profitable enterprises in agricultural allied sector like bee keeping, mushroom production, dairy farming etc. to increase their family income. Among these, bee keeping is one of the enterprise which requires small capital investment compared to the other activities. Furthermore, it does not need raw material in usual sense as nature provides the same in the form of nectar and pollen. It is a 
kind of entrepreneurship which can be carried out by any person having enthusiasm and technical skill irrespective of sex, age, education and land holding. Apart from honey, some other products like bee wax, pollen, propolis, royal jelley and bee venom can also be obtained from bee keeping which can provide an additional income to the bee keepers. In addition to this, honey bees also play an important role in increasing the yield of agricultural/horticultural crops by means of pollination and improve the quality of produce.

Singh (2000) and Monga and Manoch (2011) also reported that the honey bees increased agricultural productivity to the tune of $30-80$ per cent annually through cross-pollination. It is being increasingly realized that honey bees could be less expensive input for promoting sustainable and eco-friendly agriculture and enhancing crop productivity.

After independence, Government of India took policy decision to revive various traditional village industries and All India Kadi and Village Industry Board (KVIB) was formed in 1954.

In 1981, All India Coordinated Research Project on Honey Bees Research and Training was launched by ICAR involving agricultural universities. With the introduction of honey bee species Apismellifera into India, the growth of bee keeping industry has been phenomenal and there is a virtually honey revolution in the country. In Haryana, successful bee keeping with this exotic species was started in 1987 and at present a large number of people are engaged in this enterprise.

To improve the socio-economic status and livelihood of the farmers, rural women and unemployed youth, SainaNehwal Institute of Agricultural Technology, Training and Education (SNIATTE), Directorate of
Extension Education, Chaudhary Charan Singh Haryana Agricultural University, Hisar (Haryana) imparts vocational trainings in various fields. In this direction, the institute also conducts training on bee keeping with the objective to generate self-employment, and the people having variable social and economic background participate in this training programme. The knowledge about the socioeconomic status of bee keepers is very important in context of promotion of this activity and policy making for the welfare of such people. Therefore, the present study was undertaken with the objective to know about the socio-economic status of the trainees and perception regarding adoption of bee keeping as an entrepreneurship.

\section{Materials and Methods}

The present study was carried out at SNIATTE, Directorate of Extension Education, CCS, Haryana Agricultural University, Hisar (Haryana) during the year 2016-17. The institute organized ten training programmes (each of three days duration) on bee keeping for farmers, women and unemployed youth during the said period, in which 369 trainees participated from different districts of Haryana and adjoining states. The majority of the participants were from Hisar, Fatehabad and Sirsa districts of the state being the institute situated at Hisar.

In order to evaluate these training programmes, a study was conducted to assess the socio-economic status and perception regarding adoption of bee keeping as an entrepreneurship. For this, a performa was developed comprising general information and background of the participants such as sex, age, education level, occupation, landholding etc., and questions to evaluate each training programme. The data were tabulated and analyzed in terms of frequency and percentage using computer software MS Excel. 


\section{Results and Discussion}

\section{Social profile}

\section{Sex}

The pool of the number of participants in all the training programmes indicated that the participation of males was higher (96\%) compared to that of females (4\%) which was very low (Table 1$)$.

The lower participation of the females may be due to their inability to venture out of the house as they remain busy in household work and could not afford to spare time for such training programmes. It indicates that emphasis should be given on motivation of the rural women to participate in such vocational trainings for creation of self-employment, to make them able to contribute in family income and improve their socio-economic status.

\section{Age}

During the study, it was observed that majority of respondents (72\%) belonged to young age group (18-35 years) followed by middle age group (36-50 years) to the extent of 27 per cent. Only one per cent of the respondents were old i.e. above the age of 50 years. It shows that the youth can be successfully promoted for adopting bee keeping as an enterprise to create selfemployment. These results were in confirmation with the findings of Monniruzzamane Rehman (2009) and Lal et al., (2012).

\section{Education}

The results regarding education level of the participants revealed that the respondents having education level up to matriculation were more (47\%) followed by senior secondary to the extent of 40 per cent. Only 13 per cent candidates were having higher education level i.e. graduation and postgraduation. These results are in accordance with Lal et al., (2012) and Sharma and Dhaliwal (2014). It indicates that the youth which could not get the requisite education for gaining the employment can be engaged in the bee keeping enterprise.

\section{Social participation}

Regarding social participation, only 11 per cent of the participants reported their engagement in social activities as a member of clubs and societies at different levels i.e. village, block, district etc. It shows that the people are somewhat less interested in social welfare activities. So along with training course curriculum, it needs to emphasize on motivation of the people for such activities also.

\section{Extension contact}

It was observed that more than fifty percent of the respondents $(53 \%)$ were having low level of extension contact with the extension experts of the university and other departments. About one third of the respondents $(33 \%)$ were having medium level while only 14 per cent were having high level of extension contact with the experts. It reveals that majority of respondents (86\%) were having low to medium level of extension contact.

It implies that there is greater need to educate the people about different extension services of the university (KVKs, toll free number, magazine, and training institute) and state government departments like Agriculture and Farmer Welfare, Horticulture, Animal Husbandry etc. so that they come to know about various farmers welfare schemes and facilities provided to the people engaged in agriculture and other sectors. 


\section{Economic profile}

\section{Occupation}

Data regarding occupation highlighted that more than fifty per cent of the respondents (51\%) were having farming as an occupation followed by labor class to the extent of 26 per cent (Table 2). Only 7 per cent of the respondents were engaged in self employment. It means the farmers are adopting bee keeping as subsidiary occupation for earning additional income as it does not require special time to care of and can be easily carried out along with the farming. Among labor class also, this venture is becoming popular as an income generating source. Earlier workers, Gupta and Dogra (1997-98) have also reported the bee keeping as a vocation of poor people.

\section{Land holding}

The results revealed that the percentage of respondents having no agricultural land (landless) was higher (36\%) followed by marginal $(31 \%)$ and small farmers $(23 \%)$ having land holding up to 1 to 2 ha, respectively. Only 10 per cent of the respondents possessed land holding more than 2 hectares who can be categorized as large farmers. It shows that majority of respondents (90\%) were having zero to small land holding. It implies that the landless, marginal and small farmers can be motivated to adopt bee keeping as main profession or subsidiary occupation along with agriculture.

Also, this venture does not requires arable land and hence it can be a better option to generate or augment the family income, particularly for the landless people, as it has become difficult for such people to earn livelihood due to increasing mechanization in every field.

Table.1 Social profile of the respondents $(\mathrm{N}=369)$

\begin{tabular}{|c|c|c|c|c|c|}
\hline Sr. No. & Variables & Category & Score Range & Frequency & Percentage \\
\hline 1. & Sex & $\begin{array}{l}\text { Male } \\
\text { Female }\end{array}$ & $\begin{array}{l}-- \\
--\end{array}$ & $\begin{array}{r}356 \\
13\end{array}$ & $\begin{array}{r}96 \\
4\end{array}$ \\
\hline 2. & Age (years) & $\begin{array}{l}\text { Young } \\
\text { Middle } \\
\text { Old }\end{array}$ & $\begin{array}{l}18-35 \\
36-50 \\
>50\end{array}$ & $\begin{array}{r}266 \\
100 \\
3\end{array}$ & $\begin{array}{r}72 \\
27 \\
1\end{array}$ \\
\hline 3. & Education & $\begin{array}{l}\text { Illiterate } \\
\text { Primary } \\
\text { Middle } \\
\text { Matriculate } \\
\text { Senior Secondary } \\
\text { Graduation } \\
\text { Post Graduate }\end{array}$ & $\begin{array}{l}-- \\
-- \\
-- \\
-- \\
-- \\
-- \\
--\end{array}$ & $\begin{array}{r}21 \\
12 \\
25 \\
113 \\
147 \\
42 \\
9\end{array}$ & $\begin{array}{r}6 \\
3 \\
7 \\
31 \\
40 \\
11 \\
2\end{array}$ \\
\hline 4. & Social participation & $\begin{array}{l}\text { Yes } \\
\text { No }\end{array}$ & $\begin{array}{l}1 \\
0\end{array}$ & $\begin{array}{r}42 \\
327\end{array}$ & $\begin{array}{l}11 \\
89\end{array}$ \\
\hline 5. & Extension contact & $\begin{array}{l}\text { Low } \\
\text { Medium } \\
\text { High }\end{array}$ & $\begin{array}{r}0-16 \\
17-32 \\
33-48\end{array}$ & $\begin{array}{r}197 \\
120 \\
52\end{array}$ & $\begin{array}{l}53 \\
33 \\
14\end{array}$ \\
\hline
\end{tabular}


Table.2 Economic profile of the trainees

\begin{tabular}{|c|c|c|c|c|c|}
\hline $\begin{array}{l}\text { Sr. } \\
\text { No. }\end{array}$ & Variable & Category & $\begin{array}{l}\text { Score } \\
\text { range }\end{array}$ & Frequency & Percentage \\
\hline 1. & Occupation & $\begin{array}{l}\text { Farming } \\
\text { Self employed } \\
\text { Labor } \\
\text { Student } \\
\text { Other }\end{array}$ & $\begin{array}{l}-- \\
-- \\
-- \\
-- \\
--\end{array}$ & $\begin{array}{r}188 \\
26 \\
98 \\
10 \\
47\end{array}$ & $\begin{array}{c}51 \\
7 \\
26 \\
3 \\
13\end{array}$ \\
\hline 2. & Land holding (ha) & $\begin{array}{l}\text { Landless } \\
\text { Marginal } \\
\text { Small } \\
\text { Large }\end{array}$ & $\begin{array}{c}0 \\
<1 \\
1-2 \\
>2\end{array}$ & $\begin{array}{r}136 \\
113 \\
84 \\
36\end{array}$ & $\begin{array}{l}36 \\
31 \\
23 \\
10\end{array}$ \\
\hline 3. & $\begin{array}{l}\text { Annual income } \\
\text { (Rs.in lacs) }\end{array}$ & $\begin{array}{l}\text { Low } \\
\text { Medium } \\
\text { High }\end{array}$ & $\begin{array}{l}<1 \\
1-2 \\
>2\end{array}$ & $\begin{array}{r}267 \\
53 \\
49\end{array}$ & $\begin{array}{l}72 \\
15 \\
13\end{array}$ \\
\hline
\end{tabular}

Table.3 Assessment of training programme

\begin{tabular}{|c|l|l|c|c|}
\hline Sr. No. & Variables & Category & Frequency & Percentage \\
\hline $\mathbf{1 .}$ & Utility of training & Very useful & 265 & 72 \\
& & Useful & 82 & 22 \\
& & Somewhat useful & 22 & 6 \\
\hline $\mathbf{2 .}$ & \multirow{2}{*}{ Coverage of subject matter } & Widely covered & 245 & 66 \\
& & Moderately covered & 110 & 30 \\
& & Slightly covered & 14 & 4 \\
\hline \multirow{3}{*}{} & \multirow{2}{*}{ Excellence of training } & Excellent & 302 & 82 \\
& & Very good & 49 & 13 \\
& & Good & 18 & 5 \\
\hline
\end{tabular}

Table.4 Awareness and perception of trainees regarding the adoption of bee keeping as a vocation

\begin{tabular}{|c|l|c|c|}
\hline Sr. No. & Variables & Frequency & Percentage \\
\hline $\mathbf{1 .}$ & Any knowledge about bee keeping & 163 & 45 \\
\hline $\mathbf{2 .}$ & Existing bee keeper & 43 & 12 \\
\hline $\mathbf{3 .}$ & Facing any problem & $13^{*}$ & 30 \\
\hline $\mathbf{4 .}$ & Purpose of training & & \\
& To adopt bee keeping as a vocation & 306 & 83 \\
& To improve knowledge & 38 & 10 \\
& Just for the sake of knowledge & 19 & 5 \\
& Just to avail subsidy & 6 & 2 \\
\hline
\end{tabular}

* (out of 43) 
Int.J.Curr.Microbiol.App.Sci (2018) 7(7): 143-149 


\section{Annual income}

In case of annual income, majority of respondents $(64 \%)$ were having low level of annual income i.e. up to Rs. 1 lac only. The respondents having medium (Rs. 1-2 lacs) and high level of annual income (Above Rs. 2 lacs) were only 14 and 13 per cent, respectively. It shows that the people having low level of annual income are adopting bee keeping as an enterprise more for income generation.

\section{Impact of training programme}

\section{Utility of training}

Data presented in Table 3 and revealed that majority of respondents (72\%) reported the training very useful while some categorized it as useful (22\%) and somewhat useful (6\%). It indicates that before going to start bee keeping as a vocation, one should attend the training to learn about various aspects of the bee keeping for making it a more profitable business.

\section{Coverage of subject matter}

About $2 / 3$ of the respondents $(66 \%)$ reported that in depth knowledge was given during the training programme i.e. subject matter was covered widely. Thirty per cent of the respondents reported it as moderately covered while four per cent as slightly covered. It means there is need to make the training programme more informative so that the trainees may gain more knowledge about bee keeping and can manage the colonies efficiently.

\section{Excellence of training}

More than three fourth of the respondents $(82 \%)$ rated the training programmes as excellent whereas 13 per cent rated it very good and another five per cent as good.

\section{Awareness and adoption of bee keeping Awareness}

The data revealed that about 45 per cent of respondents thought that they had somewhat knowledge about bee keeping but only 12 per cent of them were practicing it (Table 4). It indicates that they are less confident or having not much knowledge and wanted to get or improve their knowledge by attending such type of training programme. About 30 per cent of the existing bee keepers used to face some problems like low market rate of honey, difficulty during migration and decreased population of honey bees, particularly during summer season and in absence of flora.

\section{Adoption}

As far as the adoption of bee keeping is concerned, majority of respondents (83\%) showed their eagerness to go for bee keeping for creation of self-employment. Ten per cent of the respondents wanted to improve their knowledge through training programme for betterment as they may already be engaged in the concerned activity. Only five per cent of the respondents attended the training just for the sake of knowledge and about two per cent for availing the subsidy provided by the government through various agencies. It shows that the bee keeping is becoming popular among the people as an entrepreneurship for employment generation.

On the basis of this study, it was concluded that the unemployed youth, landless labors/farmers and marginal farmers belonging to young age group and having low level of annual income are more interested in adopting bee keeping as an entrepreneurship for creation of self-employment or augmentation of their family income. Keeping in view the lower participation of the women, 
there is need to give more emphasis on their motivation for adopting such agro-based enterprise for income generation, to make them self-dependent and improving their socio-economic status.

Acknowledgment

Hereby, I acknowledge the opportunities provided by the respected Associate Director (Training) for conducted the trainings on bee keeping and gathering the information. I also acknowledge the support of my colleagues and sub ordinate staff provided during the conductance of training and preparation of this manuscript.

\section{References}

Gupta, J.K. and Dogra, G.S. 1997-98. Constraints and thrust area for the development of apiculture in India. In: R.C. Mishra (Ed): Perspectives of Indian Apiculture. Bikaner: Agro
Botanica, Pp. 1-13.

Monga, K. and Manocha, A. 2011. Adoption and constraints of be-keeping in Districts Panchkula (Haryana), India. Livestock Res. Rural Dev. 23:5

Moniruzzaman, M. and Rahman, M.S. 2009. Prospects of bee-keeping in Bangladesh. J. Bangladesh Agril. Univ. 7(1): 109-116

Ramesh Lal, Sharma, S.D., Sharma, J.K., Sharma V and Singh, D. 2012. Impact of bee-keeping training on socioeconomic status of farmers and rural youth in Kullu and Mandi districts of Himachal Pradesh. J. Hum. Ecol., 39(3): 208-08

Sharma, K. and Dhaliwal, N.S. 2014. Socioeconomic profile of successful bee keepers and profitability of bee keeping in Muktsar district of Punjab. J. KrishiVigyan. 2(2): 69-73.

Singh, D. 2000. A focus on honey bees in the tropics. Current Science. 79: 115-57.

\section{How to cite this article:}

Bhupender Singh, Surender Singh and Asha Batra. 2018. Socio Economic Status of the People Adopting Bee Keeping as an Entrepreneurship. Int.J.Curr.Microbiol.App.Sci. 7(07): 143-149. doi: https://doi.org/10.20546/ijcmas.2018.707.018 